\title{
POTENSI DAN TANTANGAN PESANTREN DALAM PEMBERDAYAAN ENTREPRENEURSHIP SANTRI
}

\author{
Muhammad Irsan Barus \\ (mirsanbarus@gmail.com) \\ Dosen Sekolah Tinggi Agama Islam Negeri Mandailing Natal \\ Kekanwil \\ Guru Sekolah Menengah Kejuruan Negeri 3 Padang
}

\begin{abstract}
Abstrak: Penelitian ini bertujuan untuk mendeskripsikan potensi dan tantangan pesantren dalam memberdayakan santri. Studi dilaksanakan di Pesantren Dr. Muhammad Natsir Kabupaten Solok. Metode penelitian yang digunakan adalah kualitatif deskriptif. Sumber utama data dalam penelitian ini ialah kata-kata dan tindakan yang mendeskripsikanpemberdayaan enterpreneurshipsantri di Pesantren Dr. Muhammad Natsir. Kata-kata tersebut dikumpulkan dengan teknik wawancara, dokumentasi dan observasi. Analisis data dilakukan dengan melalui proses reduksi data, menyajikannya dalam bentuk yang mudah dipahami dan memverifikasi data untuk mencari kebenaran. Hasil penelitian menunjukkan bahwa potensi yang dimiliki Pesantren Dr. Muhammad Natsir dalam memberdayakan santri adalah guru dan pimpinan pesantren yang memiliki kualifikasi dan kemandirian ekonomi, santri dengan berbagai bakat, sarana pendidikan dan sumber daya alam yang dimiliki secara mandiri. Tantangan yang dihadapi Pesantren Dr. Muhammad Natsir dalam pemberdayaan ekonomi adalahpembiayaan, kurangnya tenaga pelatihan serta pemasaran hasil pertanian dan hasil kreativitas santri berkutat pada masalah kesinambungan produksi, panjangnya saluran pemasaran, kurangnya informasi pasar, masih rendahnya kualitas sumber daya manusia.
\end{abstract}

Kata Kunci: Potensi, Tantangan, Pesantren, Enterpreanur, Santri

\section{Pendahuluan}

Islam memerintahkan umatnya untuk membentuk tatanan kehidupan sosial masyarakat yang adil, sejahtera, makmur dan sentosa. Masyarakat yang ingin diwujudkan Islam adalah masyarakat yang mandiri dan berdikari secara ekonomi, sosial dan politik. Untuk mencapai tujuan dan nilai mulia tersebut, maka Islam secara doktrin dan praktikal mengatur masalah ekonomi, pemberdayaan masyarakat dan hal-hal muamalah bidang bisnis dan usaha.

Secara faktual masalah krusial yang dihadapi umat Islam dewasa ini adalah masalah ekonomi. Aspek ekonomi merupakan salah satu hal penting yang harus diperbaiki melalui pemberdayaan. Banyak dari kalangan umat Islam belum terberdayakan dengan maksimal sehingga kehidupan sosial dan ekonomi sebagian besar carut marut. Kemunduran umat Islam bukan hanya terletak pada kejahilan 
terhadap syariat, tetapi juga pada ketimpangan struktur ekonomi dan sosial. Alquran juga telah menjelaskan bahwa kemiskinan bukan hanya diakibatkan oleh kemalasan individual, melainkan juga tidak adanya kolektivitas bersama membantu kaum lemah, adanya segelintir orang yang menguasai kekayaan alam dengan serakah. ${ }^{1}$

Pengentasan kemiskinan dan keterbelakangan umat Islam adalah tanggung jawab bersama. Masalah ekonomi bukan hanyalah masalah keduniawian saja akan tetapi juga berkaitan dengan pelaksanaan kegiatan keagamaan. Untuk bias melaksanakan ibadah dengan sempurna diperlukan kecukupan ekonomi. Bagaimana mungkin seseorang bisa menyempurnakan agamanya tanpa memiliki kecukupan seperti haji, zakat dan lain sebagainya.Itulah sebabnya di Surah alJumu'ah Allah memerintahkan manusia untuk mencari penghidupan agar pelaksanaan kegiatan ibadah khusus kepada Allah tidak terganggu karena keterbatasan modal.

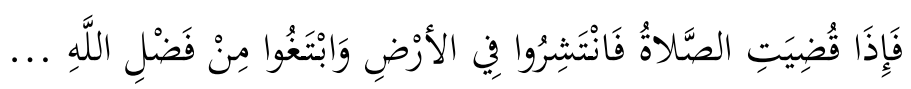

"Apabila telah selesai shalat (Jum'at) maka bertebaranlah di bumi dan carilah fadhl (kelebihan) dari Allah" (QS. Al-Jumu'ah, 62: 10)

Kemiskinan telah menghancurkan harga diri, martabat dan bahkan iman. Oleh karena itu, Islam berkepentingan agar umatnya mempunyai kemampuan dan keunggulan di bidang ekonomi. Salah satu caranya ialah agar zakat, infak dan sedekah dapat dikembangkan untuk memenuhi kebutuhan komsumtif dan pengembangan usaha produktif.

Untuk itu, sangat penting dirumuskan suatu pola pemberdayaan ekonomi umat Islam dalam sistem jaringan kerja yang efektif, baik pada sektor peningkatan kualitas sumber daya manusia (pendidikan dan pelatihan) maupun sektor dunia usaha untuk pemagangan, pengembangan produksi, perluasan pasar, serta dunia perbankan untuk sektor permodalan dan pembiayaan.

Salah satu upaya untuk mengembangkan potensi ekonomi umat dan membangun masyarakat mandiri adalah menciptakan sebanyak-banyaknya

1 Lihat QS. al-Fajr, 17-20, (17. Sekali-kali tidakdemikian), sebenarnya kamu tidak memuliakananak yatim); (18. Dan kamu tidak saling mengajak memberi makan orang miskin);(19. Dan kamumemakan harta pusaka dengan cara mencampurbaurkan (yang halal dan yang bathil); (20. Dan kamu mencintai harta benda dengan kecintaan yang berlebihan. 
enterpreneur baru. Dengan menjadi enterprener, masyarakat akan mandiri dan berdaya saing global. Cara ini bisa ditempuh dengan memberdayakan santri untuk menguasai pemahaman agama yang komprehensif serta memiliki keahlian dan skiil yang kreatif dalam bidang ekonomi.

Untuk mewujudkan cita-cita tersebut dibutuhkan kerja sama semua pihak. Selain itu, dibutuhkan sebuah lembaga yang mampu mereproduksi calon-calon entrepreneur di masa depan. Ketika seorang santri berbicara berceramah agama, ia tidak hanya berbicara tentang masalah-masalah ibadah semata, tetapi juga mampu mendeskripkan masalah-masalah ekonomi masyarakat dan memberi solusi penyelesaian masalah.

Para santri yang dibekali ilmu agama dan kemampuan enterprener akan menjadi promotor gerakan perubahan masyarakat yang masif. Mereka mampu memberdayakan ekonomi masyarakat secara kreatif, di samping juga memberikan pengertian agama secara mendalam.

Lembaga yang melahirkansantri yang memiliki jiwa enterprener adalah pesantren. ${ }^{2}$ Secara historis, pesantren mempunyai dua peran besar, yaitu peran pengembangan masyarakat dan pendidikan. ${ }^{3}$ Sebagai pusat pendidikan, pesantren telah menghasilkan alumni yang memiliki kemampuan di bidang ilmu agama dengan kualifikasi beragam. Pesantren juga menjadi pusat pembudayaan ajaran agama dan perilaku sosial yang berbasis pada pemikiran prinsip-prinsip Islam.

Pesantren adalah lembaga dakwah yang memberdayakan umat.Bahkan pesantren berperan signifikan menciptakan masyarakat madani. Ada berbagai alasan yang menjustifikasi hal tersebut.Pertama, secara teori dan praktif santri diajarkan ilmu agama yang baik.Kedua, kehidupan santri diciptakan sebagai miniatur demokratis dan egalitarian. Hal ini dijustifikasi dari keadaan santri yang hidup bersama dengan status ekonomi dan sosial yang berbeda.Ketiga, sikap toleran dan berkeadilan.Santri diajarkan hidup bersama dan diberikan pendidikan

\footnotetext{
${ }^{2}$ Pesantren sebagai bagian penting dalam pendidikan Islam di Indonesia mempunyai ciri khas, seperti adanya pondok, masjid, santri, kiai, kitab-kitab klasik.Kelima unsur tersebut menjadi karakteristik dan tolak ukur sebuah lembaga Islam dianggap sebagai pesantren. Lihat Zamakhasyari Dhofier, Tradisi Pesantren: Studi tentang Pandangan Hidup Kiai, (Jakarta: LP3ES, 1982, hlm. 18.

3 Taufik Buhari, Antologi Kajian Islam; Tinjauan Tentang Filsafat, Tasawwuf, Institusi, Pendidikan, Al-Qur'an, Hadith, Hukum dan Ekonomi Islam, (Surabaya, Pascasarjana IAIN Sunan Ampel Press, 2006), hlm. 189.
} 
yang setara.Keempat, masyarakat berilmu.Santri diajarkan berbagai macam ilmu dan keterampilan.

Lulusan pendidikan sekarang tidak hanya diharapkan hebat dalam bidang keilmuan, tetapi harus mempunyai skill dan keterampilan.Mereka harus dididik menjadi wirausahawan, yaitu seseorang yang selalu membawa perubahan, inovasi, ide-ide baru dan aturan baru. Wirausahawan, yaitu seseorang yang mempunyai dan membawa sumber daya berupa tenaga kerja, material, serta aset yang lainnya pada suatu kombinasi yang mampu melakukan suatu perubahan/ menambahkan nilai yang lebih besar daripada nilai yang sebelumnya. Jadi, ketika mereka nanti lulus sekolah, di samping mampu berdakwah, juga berhasil membuka lapangan kerja.

Pesantren Dr. Muhammad Natsir adalah salah satu pesantren yang konsisten memberdayakan santri dan masyarakat sekitarnya.Pesantren ini lahir dari keprihatinan beberapa orang guru Sekolah Menengah Atas (SMA) Alahan Panjang terhadap siswa-siswa mereka yang sering terlambat membayar uang sekolah (SPP). Setelah dipelajari lebih jauh, kondisi tersebut ternyata disebabkan oleh faktor kemiskinan. Jika dibiarkan, tidak tertutup kemungkinan dapat mengganggu hak-hak anak untuk mendapat pengajaran. Karena itu, muncul inisiatif dari beberapa orang guru Sekolah Menengah Atas (SMA) Negeri Alahan Panjang untuk mendirikan sebuah sekolah yang mampu mengatasi kesulitan masyarakat miskin untuk mendapatkan pendidikan yang layak.

Berdasarkan uraian di atas, maka penulis tertarik untuk lebih mendalami tentang Potensi dan Tantangan Pesantren dalam Pemberdayaan Santri (Studi Kasus Pesantren Dr. Muhammad Natsir Desa Batu Bagiriak, KabupatenSolok)

Metode penelitian yang digunakan adalah metode penelitian kualitatif. Metode ini dipilih untuk mengungkapkan fenomena sosial yang terjadi secara wajar. Sumber utama data dalam penelitian ini ialah kata-kata dan tindakan yang mendeskripsikanpemberdayaan enterpreneurshipsantri di Pesantren Dr. Muhammad Natsir. Kata-kata tersebut dikumpulkan dengan teknik wawancara, dokumentasi dan observasi. Wawancara dilakukan kepada beberapa guru, santri, tenaga kependidikan, pengurus yayasan serta masyarakat sekitar pesantren. Sedangkan tindakan yang dijadikan sumber data adalah tindakan berkaitan 
pemberdayaan enterpreneurshipsantri. Tindakan tersebut didokumentasikan untuk menjadi bahan telaah oleh penulis. Informan penelitian ditetapkan dengan menggunakan teknik snow ballsampling (Sampel Bola Salju) (Soekanto, 1984: 197), yaitu pencarian informasi ke berbagai pihak hingga ditemukan tingkat kejenuhan.

Pemeriksaan keabsahan data penulis lakukan dengan teknik triangulasi, yaitu teknik pengecekan keabsahan data yang dilakukan dengan menggunakan berbagai sumber, cara dan waktu. (Sugiyono, 2009: 272). Triangulasi yang akan penulis lakukan adalah triangulasi sumber (mengulangi pertanyaan yang sama kepada sumber yang berbeda); triangulasi teknik (menggunakan teknik yang berbeda kepada satu sumber) ; dan triangulasi waktu (melakukan observasi, wawancara dan dokumentasi dalam waktu yang berbeda).

Analisis data dilakukan dengan tahapan sebagai berikut: (1)mereduksi data yang dianggap relevan dengan pemberdayaan santri. (2) Penyajian data dilakukan dengan uraian yang mudah dipahami. (3) Verifikasi data dilakukan untuk mendeskripsikan kesimpulan pikiran yang menjadi fokus penelitian. Pada tahap ini, penulis akan menguraikan data pada tahap yang lebih spesifik dan mencari jawaban dari permasalahan penelitian.

\section{Pembahasan}

1. Potensi Pesantren Dr. Muhammad Natsir dalam Memberdayakan Santri Potensi ekonomi yang dimiliki Pesantren Dr. Muhammad Natsir adalah:

a. Guru dan pimpinan pesantren

Guru dan pimpinan pesantren dipandang sebagai potensi pesantren yang mempunyai nilai ekonomis, setidaknya dapat dilihat pada empat hal:

1) Kompetensi guru dan pimpinan. Artinya, figur seorang guru dan pimpinan pesantren merupakan magnet (daya tarik) bagi calon santri untuk menuntut ilmu.

2) Pada umumnya, guru dan pimpinan pesantren adalah tokoh panutan masyarakat dan pemerintah. Ketokohanmemunculkan sebuah kepercayaan, dan dari kepercayaan melahirkan akses. 
3) Pada umumnya pesantren berada di bawah naungan yayasan. Yayasan dibangun oleh orang-orang yang telah mandiri secara ekonomi.

4) Guru dan pimpinan pesantren sebelum membangun pesantren telah mandiri secara ekonomi. Jiwa dan semangat entrepreneurship inilah yang mendasari kemandirian perekonomian pesantren. Apabila aset dan jiwa entrepreneurship ini dipadukan, maka hasilnya dapat dijadikan dasar membangun tatanan ekonomi pesantren.

b. Santri

Potensi ekonomi kedua yang melekat pada pesantren adalah para santri. Hal ini dipahami bahwa pada umumnya santri mempunyai potensi/bakat bawaan seperti kemampuan membaca Alquran, kaligrafi, pertukangan, dan lain sebagainya. Bakat bawaan ini sudah seharusnya dipupuk dan dikembangkan agar menjadi produktif dan bisa menghasilkan nilai ekonomis. ${ }^{4}$

c. Pendidikan

Potensi ekonomi dari pendidikan pesantren terletak pada santri, guru, sarana dan prasarana. Dari sisi santri, dikenai kewajiban membayar SPP, di samping sumbangan-sumbangan wajib lainnya. Untuk kelancaran proses belajar mengajar, diperlukan seperangkat buku, kitab, dan alat-alat tulis. Dari sini bisa dikembangkan salah satu unit usaha pesantren yang menyediakan sarana belajar tersebut. Misalnya toko buku/kitab, alat tulis, dan photo copy. Belum lagi dari sisi kebutuhan sehari-hari, seperti makan, minum, air, telepon, asrama, pakaian, dan lain sebagainya.

d. Sumber daya alam

Pesantren Dr. Muhammad Natsir memiliki sumber daya alam yang cukup memadai untuk dijadikan kegiatan berwirausaha. Sumber daya alam itu berupa tanah garapan, kolam ikan dan usaha jasa yang dimiliki pesantren. Semua sumber daya tersebut sangat bermanfaat untuk pemberdayaan kewirausahaan santri.

\footnotetext{
${ }^{4}$ Dokumen penerimaan santri Pesantren Dr. Muhammad Natsir.
} 


\section{Tantangan Pesantren Dr. Muhammad Natsir dalam Pemberdayaan Santri}

Setiap kegiatan dan usaha perbaikan biasanya akan mendapatkan berbagai kendala. Begitu juga Pesantren Dr. Muhammad Natsir dalam menjalankan aktivitas pemberdayaan santri, mengalami berbagai kendala dan tantangan. Adapun kendala-kendala yang dihadapi Pesantren Dr. Muhammad Natsir dalam pemberdayaan enterpreneurship santri adalah: ${ }^{5}$

\section{a. Pemasaran}

Pemasaran menjadi salah satu kendala serius yang dialami Pesantren Dr. Muhammad Natsir. Hasil-hasil pertanian dan pengolahannya perlu dipasarkan untuk diketahui konsumen sehingga biaya produksi dan pengembangan usaha bisa dilaksanakan secara simultan.

Selama ini Pesantren Dr. Muhammad Natsir mengalami kendala memasarkan hasil kreativitas kewirausahaan santri sehingga pengembangan kegiatan kewirausahaan santri belum begitu berkembang. Pesantren belum memiliki akses yang cukup besar untuk mensosialisasikan produk-produk hasil kerja santri.

Pesantren sudah mencoba untuk memberi tahu masyarakat akan potensi yang dimiliki santri dengan mengikuti berbagai pameran yang diadakan Pemerintah Kabupaten Solok dan Pemerintahan Kota Solok. Namun hal itu belum membantu pesantren untuk memasarkan hasil kreativitas santri.

Beberapa kendala tersebut pemasaran yang dihadapi Pesantren Dr. Muhammad Natsir di antaranya;

1) Kesinambungan produksi

Salah satu penyebab timbulnya berbagai masalah pemasaran hasil pertanian berhubungan dengan sifat dan ciri khas produk pertanian, yaitu Pertama, volume produksi usaha Pesantren Dr. Muhammad Natsir dalam bidang holtikultura masih sangat kecil. Ini terlihat dari 60 hektar lahan, baru sekitar 25 hektar yang produktif, itu pun hanya 15 hektar yang digunakan untuk tanaman holtikultura.

\footnotetext{
${ }^{5}$ Wawancara dengan Tokoh Masyarakat Desa Batu Bagiriak dan guru Pesantren Dr. Muhammad Natsir
} 
Kedua, produksi bersifat musiman sehingga hanya tersedia pada waktu-waktu tertentu. Tanaman holtikultura yang ditanam Pesantren Dr. Muhammad Natsir umumnya berumur pendek sekitar 6 sampai 1 tahun. Hal ini membuat proses produksi pertanian tidak berkesinambungan. Ketiga, sifat produksi pertanian yang mudah rusak, berat dan memerlukan banyak tempat. Sering kali, tanaman yang baru dipetik dan tidak bisa langsung dijual akan mengalami pembusukan. Ini juga menjadi salah satu kendala yang dihadapi Pesantren Dr. Muhammad Natsir dalam memanen hasil pertanian.

2) Panjangnya saluran pemasaran

Pesantren Dr. Muhammad Natsir harus menerima bagian keuntungan yang sedikit disebabkan ongkos produksi dan pemasaran yang mahal. Panjangnya saluran pemasaran menyebabkan besarnya biaya yang dikeluarkan, serta ada bagian yang dikeluarkan sebagai keuntungan pedagang. Hal tersebut cenderung memperkecil bagian yang diterima pesantren dan memperbesar biaya yang dibayarkan konsumen.

3) Kurangnya informasi pasar

Informasi pasarmasih sangat minim diketahui oleh pimpinan Pesantren Dr. Muhammad Natsir. Kondisi tersebut menyebabkan usaha pesantren dilakukan tanpa melalui perencanaan yang matang.

4) Masih rendahnya kualitas sumber daya manusia

Rendahnya kualitas sumber daya manusia yang memasarkan hasil pertanian pesantren dan hasil kerajian santri. Pemberdayaan santri selama ini lebih banyakpraktik pengolahan lahan pertanian dan belum mengarah kepada praktik pemasaran.

b. Pembiayaan

Setiap aktivitas tentu membutuhkan dana yang tidak sedikit. Pesantren Dr. Muhammad Natsir mengharapkan bantuan dari berbagai pihak demi kemajuan pesantren, sambil berusaha memberdayakan potensi yang dimiliki pesantren agar mandiri dan tidak selamanya bergantung pada orang lain. Oleh karena itu, pesantren berusaha memanfaatkan lahan-lahan 
pertanian, perdagangan, peternakan dan perikanan seadanya untuk mendukung operasional pesantren. ${ }^{6}$

Biaya makan santri perhari, Pesantren Dr. Muhammad Natsir membutuhkan biaya sebesar Rp.2.000.000. Selain itu, Pesantren Dr. Muhammad Natsir juga harus membiyai operasional pendidikan, seperti gaji guru, gaji petani, rekening listrik, perawatan gedung dan lain sebagainya. Besarnya biaya operasional Pesantren ini membuat para pengurus Yayasan Nurul Iman dan pimpinan Pesantren Dr. Muhammad Natsir mencari dana tambahan berupa hibah dan donatur dari berbagai kalangan masyarakat.

c. Kurangnya tenaga pelatih

Tenaga pelatih yang dimiliki pesantren masih terfokus pada tim yang diutus oleh Universitas Andalas. Para pelatih yang dimiliki pesantren belum cukup memadai untuk melatih berbagai keterampilan santri.

Tenaga pelatih yang sangat dibutuhkan pesantren adalah bidang pengolahan hasil pertanian dan pemasaran. Selama ini Universitas Andalas melatih santri dan masyarakat masih terfokus pada usaha pengolahan lahan dan tanaman, sementara pada usaha pengolahan hasil pertanian dan pemasaran belum begitu memadai.

Insktruktur tetap yang dimiliki Pesantren Muhammad Natsir dalam bidang pengolahan hasil pertanian baru satu orang saja, yaitu Sugiyono. Selebihnya adalah tenaga ahli yang diperbantukan oleh Pemerintah Daerah Kabupaten Solok dan Universitas Andalas.

Pada tenaga pemasaran, Pesantren Dr. Muhammad Natsir belum memiliki tenaga ahli. Pemasaran yang selama ini dilakukan pesantren belum terencana secara matang. Hal ini bisa dilihat dari belum berkembangnya pemasaran hasil pertanian pesantren. Begitu juga hasil kreativitas santri, baru diperkenalkan pada masyarakat sekitar pesantren dan berbagai kegiatan lomba dan pameran.

\footnotetext{
${ }^{6}$ Ibid
} 


\section{Penutup}

Potensi Pesantren Dr. Muhammad Natsir dalam memberdayakan santri adalah guru dan pimpinan pesantren dengan kompetensi yang mumpuni, ketokohan dan kemandirian ekonomi. Selain itu Pesantren Dr. Muhammad Natsir juga memiliki bakat-bakat santri yang perlu dibina dan dikembangkan, sarana pendidikan yang mencukupi untuk mendukung proses pembelajaran serta sumber daya alam yang bisa menghasilkan nilai ekonomi dan bisnis

Tantangan Pesantren Dr. Muhammad Natsir dalam pemberdayaan santri adalah masalah pemasaran hasil pertanian dan kreativitas yang dihasilkan santri. Kendala-kendala pemasaran itu berkaitan dengan kesinambungan produksi, panjangnya saluran pemasaran, kurangnya informasi pasar, masih rendahnya kualitas sumber daya manusia. Selain itu juga tantangan yang dihadapi oleh Pesantren Dr. Muhammad Natsir dalam pemberdayaan santri menyangkut masalah pembiayaan dan kurangnya tenaga pelatih. 


\section{Pustaka acuan}

Dhofier, Zamakhasyari. 1982. Tradisi Pesantren: Studi tentang Pandangan Hidup Kiai. Jakarta: LP3ES.

Taufik Buhari, Antologi Kajian Islam; Tinjauan Tentang Filsafat, Tasawwuf, Institusi, Pendidikan, Al-Qur'an, Hadith, Hukum dan Ekonomi Islam, (Surabaya, Pascasarjana IAIN Sunan Ampel Press, 2006) 